Article

\title{
Antioxidant and Biological Activities of Acacia saligna and Lawsonia inermis Natural Populations
}

\author{
Hosam O. Elansary $1,2,3, * \mathbb{E}$, Agnieszka Szopa ${ }^{4, * \mathbb{C}}$, Paweł Kubica ${ }^{4} \mathbb{D}^{\circ}$, Halina Ekiert ${ }^{4}$, \\ Fahed A. Al-Mana ${ }^{1}$ and Mohammed A. Al-Yafrsi ${ }^{1}$ \\ 1 Plant Production Department, College of Food and Agricultural Sciences, King Saud University, \\ P.O. Box 2455, Riyadh 11451, Saudi Arabia; falmana@ksu.edu.sa (F.A.A.-M.); \\ malyafrsi@ksu.edu.sa (M.A.A.-Y.) \\ 2 Floriculture, Ornamental Horticulture, and Garden Design Department, Faculty of Agriculture (El-Shatby), \\ Alexandria University, Alexandria 21545, Egypt \\ 3 Department of Geography, Environmental Management, and Energy Studies, University of Johannesburg, \\ APK Campus, Johannesburg 2006, South Africa \\ 4 Department of Pharmaceutical Botany, Medical College, Jagiellonian University, ul. Medyczna 9, \\ 30-688 Kraków, Poland; p.kubica@uj.edu.pl (P.K.); halina.ekiert@uj.edu.pl (H.E.) \\ * Correspondence: helansary@ksu.edu.sa (H.O.E.); a.szopa@uj.edu.pl (A.S.); \\ Tel.: +966-581216322 (H.O.E.); +48-12-6205436 (A.S.)
}

Received: 7 July 2020; Accepted: 15 July 2020; Published: 17 July 2020

\begin{abstract}
Acacia saligna and Lawsonia inermis natural populations growing in Northern Saudi Arabia might be a valuable source of polyphenols with potent biological activities. Using high-performance liquid chromatography-diode array detection (HPLC-DAD), several polyphenols were detected tentatively in considerable amounts in the methanolic leaf extracts of A. saligna and L. inermis. A. saligna mainly contained rutoside, hyperoside, quercetin 3-glucuronide, gallic acid and $p$-coumaric acid, whereas those of $L$. inermis contained apigenin 5 -glucoside, apigetrin and gallic acid. Strong antioxidant activities were found in the leaf extracts of both species due to the presence of hyperoside, quercetin 3 -glucuronide, gallic acid, isoquercetin, $p$-coumaric acid, quercitrin and rutoside. A. saligna and L. inermis leaf extracts as well as hyperoside, apigenin 5-glucoside, and quercetin 3-glucuronide significantly reduced reactive oxygen species accumulation in all investigated cancer cells compared to the control. Methanolic leaf extracts and identified polyphenols showed antiproliferative and cytotoxic activities against cancer cells, which may be attributed to necrotic cell accumulation during apoptotic periods. Antibacterial activities were also found in both species leaf extracts and were twice as high in A. saligna than L. inermis due to the high composition of rutoside and other polyphenols. Finally, strong antifungal activities were detected, which were associated with specific phenols such as rutoside, hyperoside, apigenin 5-glucoside and $p$-coumaric acid. This is the first study exploring the polyphenolic composition of $A$. saligna and L. inermis natural populations in northern Saudi Arabia and aiming at the detection of their biological activities.
\end{abstract}

Keywords: Acacia saligna; Lawsonia inermis; polyphenols; antioxidant; antiproliferative; cytotoxicity; antibacterial; antifungal

\section{Introduction}

Natural populations of medicinal plants are considered as important sources of natural compounds that may have bio/pharmacological activities. Large portions of the global population are reliant on these botanical remedies as traditional or alternative medicine, while others consume or utilize these 
plants and their products as nutritional supplements [1]. Natural compounds such as polyphenols display interesting medicinal properties. These polyphenols may reduce certain age-associated diseases such as cancer and Alzheimer's disease by mitigating increased cellular damage through the reduction of reactive oxygen species (ROS) by the down-regulation of antioxidant enzymes [2,3] and the modulation of the inflammatory status, autophagy function and gut microbiota [4]. The antiproliferative and cytotoxic effects of polyphenols on cancer cells are attributed to cell cycle arrest and the molecular regulation of specific genes [5-9]. Polyphenols may control microbes such as bacteria and fungi $[10,11]$ and might be used as natural food preservatives [12]. Medicinal and aromatic plant polyphenols available in different parts of the plant (leaves, stems, flowers, seeds and bark) were successful in controlling foodborne pathogens such as Escherichia coli, Staphylococcus aureus, and Bacillus cereus; human pathogenic fungi such as Candida albicans; and plant pathogenic molds such as Penicillium funiculosum $[6,13,14]$.

Acacia (wattle) are woody species belonging to the pea family (Fabaceae), and this genus comprises over 1350 species that are distributed in the warm regions of the world, including Australia, the Americas, Africa and Asia [15]. Acacia saligna (Labill.) Wendl is an invasive, fast-growing woody tree in Saudi Arabia that produces seeds that have a considerable amount of protein (18.25\% to $35.5 \%$ ) [15]. However, the polyphenol profile of $A$. saligna is quite unknown. Previous investigations have shown that Egyptian A. saligna leaf extracts may qualitatively contain flavonoids-e.g., quercetin, quercitrin, apigenin, apigenin 7-glucoside, astragalin, luteolin, myricetin, myricitrin and kaempferol, and phenolic acids-e.g., gallic acid, and catechins such as catechin and 7-galloylcatechin [16,17]. Another study on the flower's extracts detected flavonoids such as quercetin, naringenin and kaempferol and phenolic acids such as benzoic acid, caffeic acid, $o$-coumaric acid, $p$-hydroxybenzoic acid and ellagic acid [18].

Few studies have investigated the biological activities of the flower and leaf extracts of Acacia species, particularly A. saligna. Egyptian A. saligna flower water extracts showed weak antioxidant and antibacterial activities but good antifungal activity [18]. Egyptian Acacia nilotica and Acacia seyal leaf extracts showed higher antioxidant activities than Acacia laeta extracts [19]. A study on the aerial parts of Acacia species (A. salicina, A. laeta, A. hamulosa, and A. tortilis) from an eastern region of Saudi Arabia (approximately 700-1000 km from the Riyadh region) revealed that A. laeta and A. hamulosa have cytotoxic activities against HepG2 and breast cancer cell line [20]. Other Acacia species flower extracts showed allelopathic effects against Hordeum murinum [21]. However, to our best knowledge, this is the first investigation into the antioxidant, cytotoxic and antimicrobial activities of Saudi natural populations of A. saligna.

Lawsonia inermis (henna tree or Egyptian privet) is the natural source of the dye henna which is commonly used to dye skin and hair worldwide. The plant belongs to the family Lythraceae and is native to Africa, Asia and northern Australia. The leaves are used traditionally for the preparation of henna dye. The natural constituents of L. inermis are lawsone (2-hydroxy-1,4-naphthoquinone), essential oil, tannins, terpenoids, lipids, coumarins, flavonoids: linarigenin (4'-methoxyapigenin), apigenin 7-glucoside, apigenin-glucoside, luteolin, luteolin 7-glucoside, cosmosiin, and phenolic acids: gallic acid and $p$-coumaric acid [22]. Previous investigations on Tunisian L. inermis revealed that the butanolic fraction of leaves have strong antioxidant activities, and these activities were attributed to phenolic glycosides including 1,2,4-trihydroxynaphthalene-1-O- $\beta$-d-glucopyranoside [23]. In another study, the Tunisian L. inermis leaf and seed aqueous extracts showed antioxidant activities, but no active compounds were identified [24]. Iranian L. inermis aqueous leaf extracts showed diverse antioxidant activities associated with ecotypes [25]. Indian L. inermis had significant antioxidant activities that inhibited $\mathrm{Cr}$ (VI)-induced cytotoxicity in MDA-MB-435S breast cancer cells [26]. No antioxidant, cytotoxic or antimicrobial studies were conducted on Saudi L. inermis natural populations. These populations may have unique phytochemical profiles and could be considered as rich sources of secondary metabolites.

In the current study, the polyphenolic composition and biological effects of natural populations of A. saligna and L. inermis growing in the northern region of Saudi Arabia were explored. The polyphenol compounds were tentatively estimated qualitatively and quantitatively using the high-performance 
liquid chromatography-diode array detection (HPLC-DAD) method. The antioxidant activities of the methanolic extracts and identified polyphenols were investigated by three methods. The antiproliferative and cytotoxic activities were studied against different human cancer cells. The antibacterial and antifungal activities of leaf extracts and identified polyphenols were examined for the first time against a wide spectrum of microorganisms.

\section{Materials and Methods}

\subsection{Plant Material and Preparation}

Leaves of Acacia saligna (Labill.) Wendl and Lawsonia inermis L. were obtained from natural populations growing in the northern Riyadh region, Saudi Arabia. Plants were identified and vouchered at the College of Food and Agricultural Sciences, King Saud University, Riyadh (Hosam0002217-106) by Hosam Elansary. To obtain leaf extracts, fresh leaves were lyophilized, powdered and then extracted with methanol $\left(0.5 \mathrm{~g}\right.$ dry weight (DW)) in $10 \mathrm{~mL}$ twice by sonication for $30 \mathrm{~min}$ at $30^{\circ} \mathrm{C}$. Purification was conducted using Whatman paper; then, the residues were dried at $25^{\circ} \mathrm{C}$ (to eliminate the methanol) then frozen at $-80^{\circ} \mathrm{C}$. For HPLC study, the residues were dissolved in methanol $(1 \mathrm{~mL}$; Merck, Kenilworth, NJ, USA), whereas for bioassays, methanol was totally removed using a rotary evaporator [27]. All experiments were approved by the College of Agriculture, Alexandria University, Egypt (2018-2020-4275). Bacteria, fungi and cancer cell lines (American Type Culture Collection) were obtained from the Faculty of Agriculture, Alexandria, Egypt.

\subsection{Analyses of Phenolic Compounds}

The qualitative and quantitative estimations were performed by high-pressure liquid chromatography (HPLC) analysis using a Merck-Hitachi liquid chromatograph (LaChrom Elite, Berlin, Germany) with an L-2455 diode array detector (DAD). The used analytical column was Purospher RP-18e solid phase column $(250 \times 4 \mathrm{~mm} ; 5 \mu \mathrm{m}$, Merck, Kenilworth, NJ, USA). As the eluent for the gradient program, we used $\mathrm{A}-$ methanol and $\mathrm{B}-\mathrm{a} 0.5 \%$ acetic acid and methanol mixture 1:4 $(v / v)$. The solvent ratio changed over time as follows: $0-20 \mathrm{~min}, 100 \% \mathrm{~B} ; 20-35 \mathrm{~min}, 100-80 \%$ B; 35-55 $\mathrm{min}, 80-60 \% \mathrm{~B}$; 55-70 $\mathrm{min}, 60-0 \% \mathrm{~B} ; 70-75 \mathrm{~min}, 75-90 \mathrm{~min}, 100 \% \mathrm{~B}$. The flow rate was $1 \mathrm{~mL} / \mathrm{min}$ and the sample injection volume was $10 \mu \mathrm{L}$. Temperature was maintained at $25^{\circ} \mathrm{C}$. The DAD analytical waveband ranged from 200 to $400 \mathrm{~nm}$. Quantitative analysis was conducted at $254 \mathrm{~nm}$. The HPLC validation was carried out earlier $[28,29]$. Compounds contained in extracts were identified by comparing their retention times and UV spectra with standards. Quantitative measurements were conducted using calibration curves (Figure S1).

For the HPLC analysis, 46 standard substances were used (Sigma-Aldrich, Berin, Germany) from two chemical groups: phenolic acids and their derivatives (25 compounds)-bensoic acid, 3-phenylacetic acid, caffeic acid, caftaric acid, chlorogenic acid, cinnamic acid, $m$-coumaric acid, $o$-coumaric acid, $p$-coumaric acid $\left(\mathrm{y}=31,143,463.3 \mathrm{x}+37,623.6, \mathrm{R}^{2}=0.999\right)$, cryptochlorogenic acid, 3,4-dihydroxyphenylacetic acid, elagic acid, ferulic acid, gallic acid ( $\mathrm{y}=71,108,023.2 \mathrm{x}+$ $\left.11,440.5, R^{2}=0.999\right)$, gentisic acid, $p$-hydroxybenzoic acid, hydroxycaffeic acid, isochlorogenic acid, neochlorogenic acid, phenylacetic acid, protocatechuic acid, rosmarinic acid, salicylic acid, syringic acid and vanillic acid-as well as flavonoids (21 compounds) —apigenin ( $\mathrm{y}=59,476,721.1 \mathrm{x}$ $\left.-1,168,407.0, R^{2}=0.999\right)$, apigenin 5-glucoside $\left(y=38,556,890.2 x-563,218.5, R^{2}=0.999\right)$, apigetrin, cynaroside, hyperoside $\left(\mathrm{y}=83,592,227.7 \mathrm{x}-69.9, \mathrm{R}^{2}=0.998\right)$, isoquercetin $(\mathrm{y}=88,387,200.2 \mathrm{x}+$ $\left.113,000.0, R^{2}=0.999\right)$, kaempferol, kaempferol-7 rhamnoside, luteolin, myricetin, naringin, populin, quercetin ( $\left.\mathrm{y}=67,269,930.4 \mathrm{x}-813,339.4, \mathrm{R}^{2}=0.999\right)$, quercetin 3-glucuronide ( $\mathrm{y}=81,939,087.5 \mathrm{x}-$ 794,095.4, $\left.R^{2}=0.999\right)$, quercimetrin, quercitrin, rhamnetin, robinin, rutoside $(y=59,420,774.0 x+$ $\left.66,560.0, R^{2}=0.999\right)$, trifolin and vitexin. 


\subsection{Antioxidant Activity}

The antioxidant activities of leaf extracts of $A$. saligna and L. inermis were determined using ferric reducing antioxidant power (FRAP), $\beta$-carotene bleaching and 2,2-diphenyl-1-picrylhydrazyl (DPPH) assays [30-34]. The amount of leaf extracts required to scavenge $50 \%$ of $\beta$-carotene bleaching/DPPH solution/FRAP reagent was defined as the $\mathrm{IC}_{50}(\mu \mathrm{g} / \mathrm{mL})$ and was determined by plotting the inhibition percent against extract concentration.

In the DPPH experiments, $5 \mathrm{~mL}$ of $0.004 \%$ methanolic DPPH solution was added to methanolic leaf extracts serial concentrations, then incubated for $30 \mathrm{~min}$ at room temperature in the dark. Finally, the absorbance was measured at $517 \mathrm{~nm}$. The DPPH-free radical inhibition was determined as follows:

The percentage inhibition of antioxidant activity (IAA) was calculated in triplicate:

$$
\mathrm{IAA}=\frac{\left(A B_{5170 n m}\right)_{C}-\left(A B_{517 n m}\right)_{s}}{\left(A B_{517 n m}\right)_{C}} \times 100
$$

where $\left(A B_{5170 n m}\right)_{C}$ and $\left(A B_{517 n m}\right)_{s}$ are Abs.517 $\mathrm{nm}$ of the control and sample, respectively.

The inhibition concentration of each sample was compared with that of the BHT (butylated hydroxytoluene) as a positive control and blank.

In the $\beta$-carotene-bleaching assay, the mixture was prepared by dissolving the $\beta$-carotene $(0.5 \mathrm{mg})$ in chloroform $(1 \mathrm{~mL})$, then adding linoleic acid $(25 \mu \mathrm{L})$ and Tween $40(200 \mathrm{mg})$. A vacuum evaporation was used to remove the chloroform; finally, the distilled water was added $(100 \mathrm{~mL})$ and followed by vigorous shaking. The mixture $(2.5 \mathrm{~mL})$ was added to serial concentrations of leaf extracts, then incubated for $48 \mathrm{~h}$ at room temperature, and the absorbance was measured at $470 \mathrm{~nm}$.

In the FRAP assay, aliquots $(100 \mu \mathrm{L})$ of leaf extracts/Trolox (Sigma-Aldrich, Berlin, Germany) were added to the prepared FRAP reagent $(3 \mathrm{~mL})$, then mixed vigorously and incubated for $30 \mathrm{~min}$ at $37^{\circ} \mathrm{C}$. The calibration procedure of FRAP was conducted by applying serial dilutions of Trolox $(0-0.5 \mathrm{mmol} / \mathrm{L})$, as standard. The absorbance was determined at $593 \mathrm{~nm}$ for FRAP. All antioxidant experiments were conducted in triplicates and repeated thrice.

\subsection{Detection Intercellular ROS Accumulation}

To assay the capacity of A. saligna and L. inermis methanolic extracts as well as identified polyphenols to reduce the intracellular levels of ROS in HeLa, Jurkat, T24, and MCF-7 cancer cells, the fluorogenic dye $\mathrm{H}_{2}$ DCF-DA was used. Following passive diffusion into the cells, $\mathrm{H}_{2}$ DCFDA was deacetylated using esterases into the nonfluorescent compound. That compound was oxidized by ROS and converted to the highly fluorescent $2^{\prime}, 7^{\prime}$-dichlorofluorescein (DCF) [35]. Cells were grown in 96-well plates at a density of $1 \times 10^{4}$ cells per well for $24 \mathrm{~h}$ before experiments; then, the culture medium was changed on $10 \mu \mathrm{M} \mathrm{H}_{2}$ DCFDA (Sigma Aldrich, St. Louis, MO, USA) in serum-free medium (MEM) and incubated for $45 \mathrm{~min}$ before applying treatments. Then, cancer cells were exposed to plant extracts and identified polyphenol DPPH IC 50 values. Cells treated with $1 \mathrm{mM}$ hydrogen peroxide $\left(\mathrm{H}_{2} \mathrm{O}_{2}\right)$ were considered as a positive control. The DCF fluorescence was measured after $90 \mathrm{~min}$ using a microplate reader FilterMax F5 (Thermo Fisher Scientific, Waltham, MA, USA) at $485 \mathrm{~nm}$.

\subsection{Anticancer Activities}

Antiproliferative and cytotoxic effects of the leaf extracts of A. saligna and L. were tested against HeLa, HT-29, Jurkat, MCF-7 and HEK-293 (normal human cells) [5,13,31,36]. To study the antiproliferative effects on cell viability, a 3-(4,5-dimethylthiazol-2-yl)-2,5-diphenyltetrazolium bromide (MTT) assay was used. Leaf extracts were solubilized in DMSO (1\%) then added to standard media (MEM) containing (10\% FBS, $0.1 \mathrm{mM}$ non-essential amino acids, $17.8 \mathrm{mM} \mathrm{NaHCO}$, and $1 \mathrm{mM}$ sodium pyruvate) and cancer cells in $75 \mathrm{~cm}^{2}$ flasks. The cancer cells were prepared in microtiter plates at $4 \times 10^{-4}$ cells per $\mu \mathrm{L}$ in $270 \mu \mathrm{L}$ medium for $48 \mathrm{~h}\left(37^{\circ} \mathrm{C}, 5 \% \mathrm{CO}_{2}\right)$. Leaf extract serial concentrations were used until final concentrations of 50,100, 200, $300 \mathrm{and} 400 \mu \mathrm{g} / \mathrm{mL}$ were reached. Then, a washing 
procedure was performed using PBS. The MTT was dissolved in PBS then added (12 mM) to the medium. Finally, isopropanol $(0.04 \mathrm{~N} \mathrm{HCl})$ was mixed with the MTT solution, and the mixture was incubated at room temperature for $40 \mathrm{~min}$. A negative control (untreated) and positive couple (vinblastine sulfate and taxol) were used. To calculate the inhibition activity percentage (IAA) obtained from measuring the absorbance at a $570 \mathrm{~nm}$ wavelength, the following equation was used:

$$
I A A=\frac{\left(A B_{570 n m}\right)_{C}-\left(A B_{570 n m}\right)_{s}}{\left(A B_{570 n m}\right)_{C}} \times 100
$$

where $A B$ is the absorbance and $\left(A B_{570 n m}\right)_{C}$ and $\left(A B_{570 n m}\right)_{s}$ are Abs.570 nm of the control and sample, respectively.

The percentage of viable cells was plotted against the extract concentration $\left(\mu \mathrm{g} \mathrm{mL}{ }^{-1}\right)$ to determine the $\mathrm{IC}_{50}$. The $\mathrm{IC}_{50}$ amounts were applied in the flow cytometry assay to study the cytotoxic activities of A. saligna and L. inermis leaf extracts; then, the apoptotic cell populations were determined (FACScan, New York, NY, USA) $[5,13,36,37]$. The assay was based on monitoring phosphatidylserine translocation in the Annexin [38]. In viable cells, the phosphatidylserine is located in the inner layer of the plasma membrane. Early apoptosis starts when the phosphatidylserine translocates from the inner to the outer layer of the plasma membrane, and apoptotic cells are reflected by measuring the binding of Annexin V-FITC to external phosphatidylserine. The flow cytometer data were presented in quadrants as percentages: lower left, viable cells; upper left, necrotic cells; lower right, early apoptotic cells; and upper right, late apoptotic cells.

\subsection{Antibacterial Effect}

Bacterial isolates of Listeria monocytogenes (clinical isolate), Escherichia coli (ATCC 35210), Staphylococcus aureus (ATCC 6538), Bacillus cereus (ATCC 14579), Micrococcus flavus (ATCC 10240) and Pseudomonas aeruginosa (ATCC 27853) were used in this experiment. A microtiter plate-based protocol (micro-dilution) was used following the procedure in [14,39-41], by preparing serial concentrations of A. saligna and L. inermis extracts that were mixed with bacterial inoculum at $1.0 \times 10^{4} \mathrm{CFU}$ in each well with $100 \mu \mathrm{L}$ tryptic soy broth per well, then incubated for one day at $37^{\circ} \mathrm{C}$ in a rotary shaker. The minimum inhibitory concentration (MIC) was defined as the lowest concentration that caused no visible growth by a binocular microscope. The minimum bactericidal concentration (MBC) was determined using the serial subculturing of extracts $(2 \mu \mathrm{L})$, and the minimal concentration causing the elimination of $99.5 \%$ of each inoculum was considered as the MBC value. The optical density (OD) was determined using a $655 \mathrm{~nm}$ wavelength. A positive control (streptomycin) at $0.01-10 \mathrm{mg} / \mathrm{mL}$ was used alongside the negative one (DMSO, $1 \%$ ).

\subsection{Antifungal Effect}

A. saligna and L. inermis antifungal effects were determined against P. ochrochloron (ATCC 48663), A. ochraceus (ATCC 12066), C. albicans (ATCC 12066), A. niger (ATCC 6275), A. flavus (ATCC 9643) and P. funiculosum (ATCC 56755) using a micro-dilution method $[37,39,40]$. The MIC was determined by a stereomicroscope. The minimum fungicidal concentration (MFC) was determined by preparing serial dilutions of $2 \mu \mathrm{L}$ extracts in sub-cultures of fungi at $28^{\circ} \mathrm{C}$ for $72 \mathrm{~h}$ in microtiter plates that contained $100 \mu \mathrm{L}$ of broth medium. Ketoconazole (KTZ, 1-3500 $\mu \mathrm{g} / \mathrm{mL})$ was used as a positive control; DMSO (1\%) was also used.

\section{Results}

\subsection{A. saligna and L. inermis Polyphenol Profiling of Leaf Extracts}

A. saligna and L. inermis methanolic leaf extracts polyphenols were determined tentatively with the HPLC-DAD method to detect chosen phenolic acids and flavonoids. A. saligna methanolic leaf 
extracts contained phenolic acids such as gallic acid, at $136.2 \mathrm{mg} / 100 \mathrm{~g} \mathrm{DW}$, and $p$-coumaric acid, at $34.8 \mathrm{mg} / 100 \mathrm{~g}$ DW. High amounts of flavonoid were detected including rutoside, at $1533.0 \mathrm{mg} / 100 \mathrm{~g}$ DW; hyperoside (quercetin 3-galactoside), at $632.5 \mathrm{mg} / 100 \mathrm{~g}$ DW; quercetin 3-glucuronide, at $125.5 \mathrm{mg} / 100 \mathrm{~g}$ DW; isoquercetin, at $73.2 \mathrm{mg} / 100 \mathrm{~g}$ DW; and quercetin, at $6.1 \mathrm{mg} / 100 \mathrm{~g}$ DW (Table 1 and Figure 1A).

L. inermis leaf extracts contained high amounts of apigetrin, at $1180.9 \mathrm{mg} / 100 \mathrm{~g}$ DW; apigenin 5-glucoside, at $596.3 \mathrm{mg} / 100 \mathrm{~g}$ DW; and gallic acid, at $81.0 \mathrm{mg} / 100 \mathrm{~g}$ DW (Table 1 and Figure 1B).
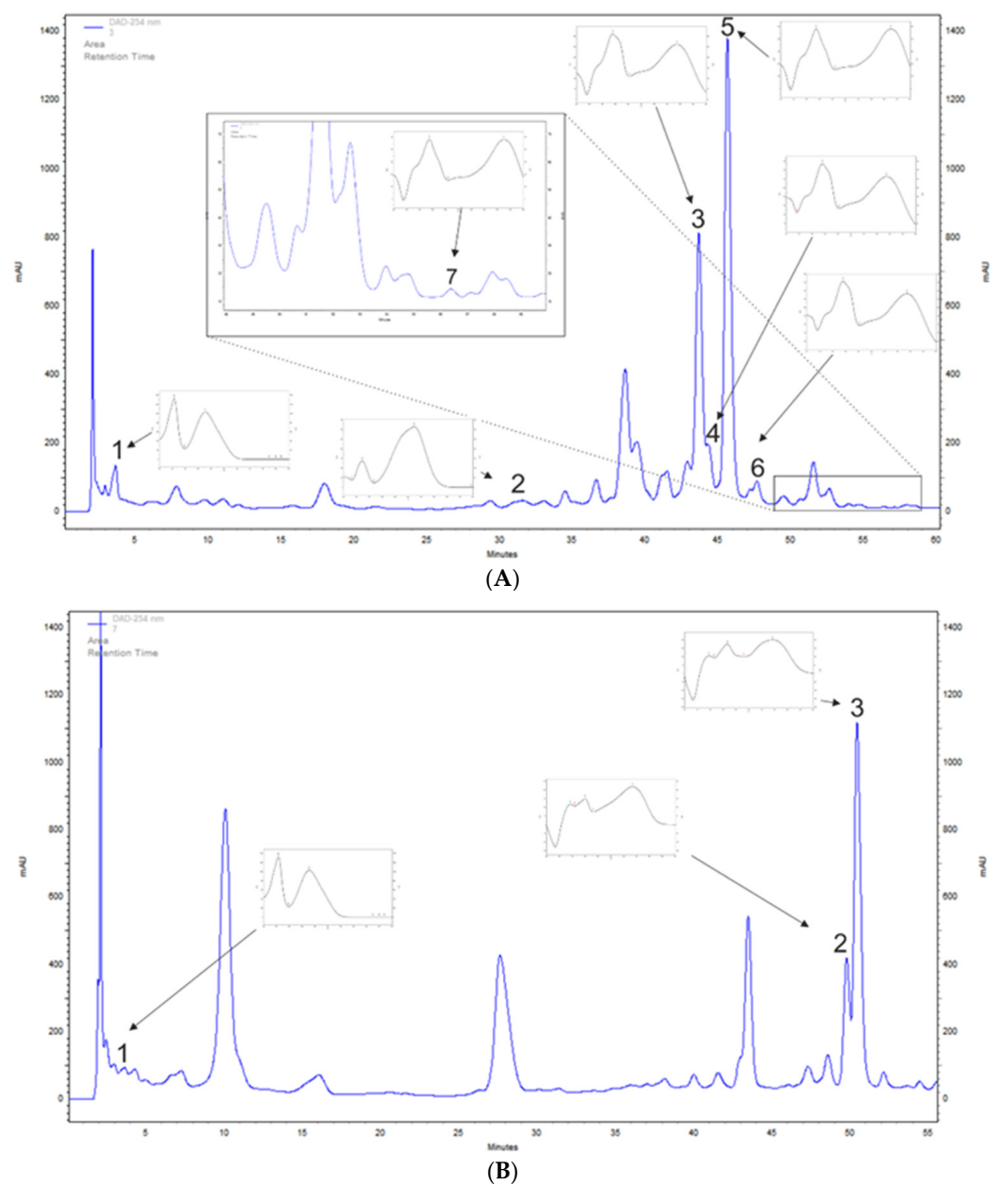

Figure 1. Examples of high-performance liquid chromatography-diode array detection (HPLC-DAD)-based separation $(\lambda=254 \mathrm{~nm}$ ) of leaf extracts of (A) Acacia saligna: 1, gallic acid; 2 , $p$-coumaric acid; 3 , hyperoside; 4 , quercetin 3-glucuronide; 5 , rutoside; 6 , isoquercetin; 7 , quercetin; and (B) Lawsonia inermis: 1, gallic acid; 2, apigenin 5-glucoside; 3, apigetrin.

Table 1. Polyphenol contents of A. saligna and L. inermis leaf extracts (mg/100 g dry weight (DW) \pm SD).

\begin{tabular}{cccc}
\hline \multicolumn{2}{c}{ Compounds } & Acacia saligna & Lawsonia inermis \\
\hline \multirow{2}{*}{ Phenolic acids } & Gallic acid & $136.2 \pm 11.1$ & $81.0 \pm 13.2$ \\
& p-Coumaric acid & $34.8 \pm 2.9$ & nd $^{*}$ \\
\hline & Hyperoside & $632.5 \pm 45.5$ & nd \\
& Isoquercetin & $73.2 \pm 9.2$ & nd \\
Flavonoids & Quercetin & $6.1 \pm 0.5$ & nd \\
& Quercetin 3-glucuronide & $125.5 \pm 2.5$ & nd \\
& Rutoside & $1533.0 \pm 55.7$ & nd \\
& Apigetrin & nd & $1180.9 \pm 153.3$ \\
& Apigenin 5-glucoside & nd & $596.3 \pm 49.1$ \\
\hline
\end{tabular}

Values are expressed as mean \pm standard deviation (SD). $n d{ }^{*}$ not detected. 


\subsection{Antioxidant Effects}

A. saligna and L. inermis methanolic extracts showed antioxidant activities comparable to the identified polyphenols, as shown in Figure 2. A. saligna showed significantly higher antioxidant activity than L. inermis as measured by different assays (DPPH, B-carotene bleaching and FRAP). In A. saligna, the identified polyphenols including hyperoside, quercetin 3-glucuronide, gallic acid, isoquercetin, $p$-coumaric acid and quercitrin showed strong antioxidant activities, with quercetin 3-glucuronide having the lowest $\mathrm{IC}_{50}$ value. In L. inermis, identified polyphenols including apigetrin and apigenin 5-glucoside showed strong antioxidant effects. Quercetin 3-glucuronide, gallic acid and $p$-coumaric acid antioxidant activities were comparable to antioxidant standards.

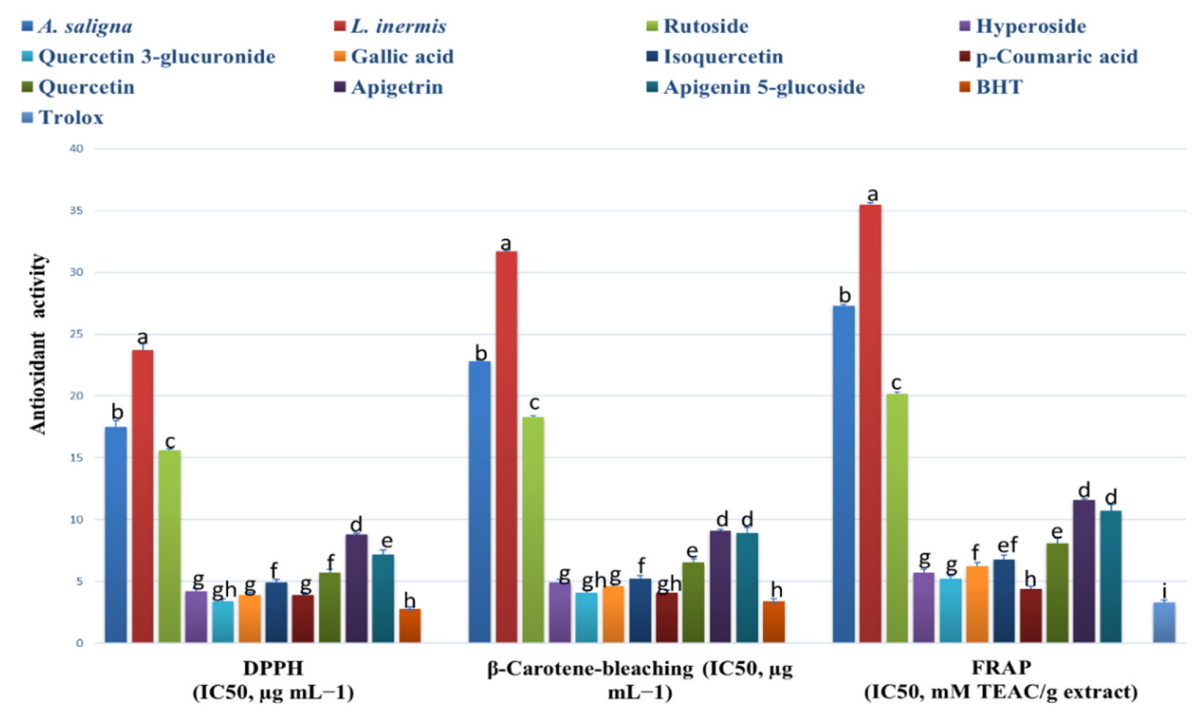

Figure 2. A. saligna and L. inermis antioxidant effects using 2,2-diphenyl-1-picrylhydrazyl (DPPH), $\beta$-Carotene bleaching and ferric reducing antioxidant power (FRAP) assays (expressed as $\mathrm{IC}_{50}$ in $\mu \mathrm{g} / \mathrm{mL}$ ). Identified polyphenol (rutoside, hyperoside, quercetin 3-glucuronide, gallic acid, isoquercetin, p-coumaric acid, quercitrin, apigetrin and apigenin 5-glucoside) antioxidant effects were also added. Values are expressed as mean \pm standard deviation. TEAC: Trolox equivalent antioxidant capacity. Different letters among group of columns indicate significant differences $(p \leq 0.05)$.

\subsection{MTT Assay and Flow Cytometry}

The MTT assay was employed to determine the antiproliferative activities of methanolic leaf extracts and the identified polyphenols against an array of cancer cells (Figure 3). Strong antiproliferative effects were exhibited by A. saligna and L. inermis leaf extracts as well as the identified polyphenols against all cells except the normal cells of HEK-293 (showing $\mathrm{IC}_{50}$ values $>400 \mu \mathrm{g} \mathrm{mL}{ }^{-1}$ ). A. saligna showed significantly higher antiproliferative activities than $L$. inermis. Strong antiproliferative activities were detected when using identified polyphenols including rutoside, hyperoside, quercetin, quercetin 3 -glucuronide and $p$-coumaric acid against cancer cells.

The cytotoxic activities of $A$. saligna and L. inermis leaf extracts as well as hyperoside, apigenin 5-glucoside and quercetin 3-glucuronide were investigated by monitoring phosphatidylserine translocation in the annexin assay (Figure 4). In viable cells, the phosphatidylserine is located in the inner layer of the plasma membrane. Early apoptosis starts when the phosphatidylserine translocates from the inner to the outer layer of the plasma membrane, and apoptotic cells are reflected by measuring the binding of Annexin V-FITC to external phosphatidylserine. The flow cytometry showed the apoptotic cell accumulation following $48 \mathrm{~h}$ of exposure in the upper and lower-right quadrant. The cytotoxic activities of A. saligna and L. inermis leaf extracts as well as major identified polyphenols were confirmed. The cell death was induced by the leaf extracts hyperoside, quercetin 3-glucuronide (Q3G) and apigenin 5-glucoside (A5G). 


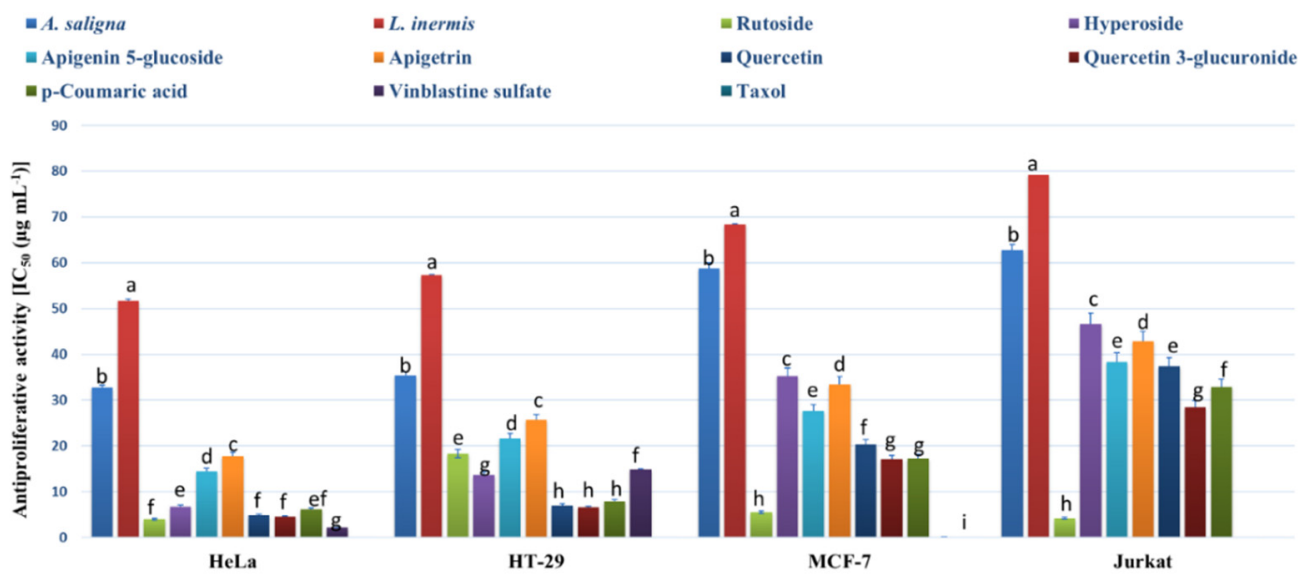

Figure 3. Antiproliferative activity $\left(\mathrm{IC}_{50}\left(\mu \mathrm{g} \mathrm{mL} \mathrm{L}^{-1}\right)\right)$ of $A$. saligna and L. inermis methanolic extracts, rutoside, hyperoside, apigenin 5-glucoside, apigetrin, quercetin and $p$-coumaric acid against cancer cells: cervical adenocarcinoma (HeLa), T-cell lymphoblast like (Jurkat), breast adenocarcinoma cultures (MCF-7), colon adenocarcinoma (HT-29) and HEK-293 (normal human cells). HEK-293 was not presented in the figure and showed $\mathrm{IC}_{50}$ values $>400 \mu \mathrm{g} \mathrm{mL} \mathrm{L}^{-1}$ for all extracts and polyphenols. Different letters among group of columns indicate significant differences $(p \leq 0.05)$.

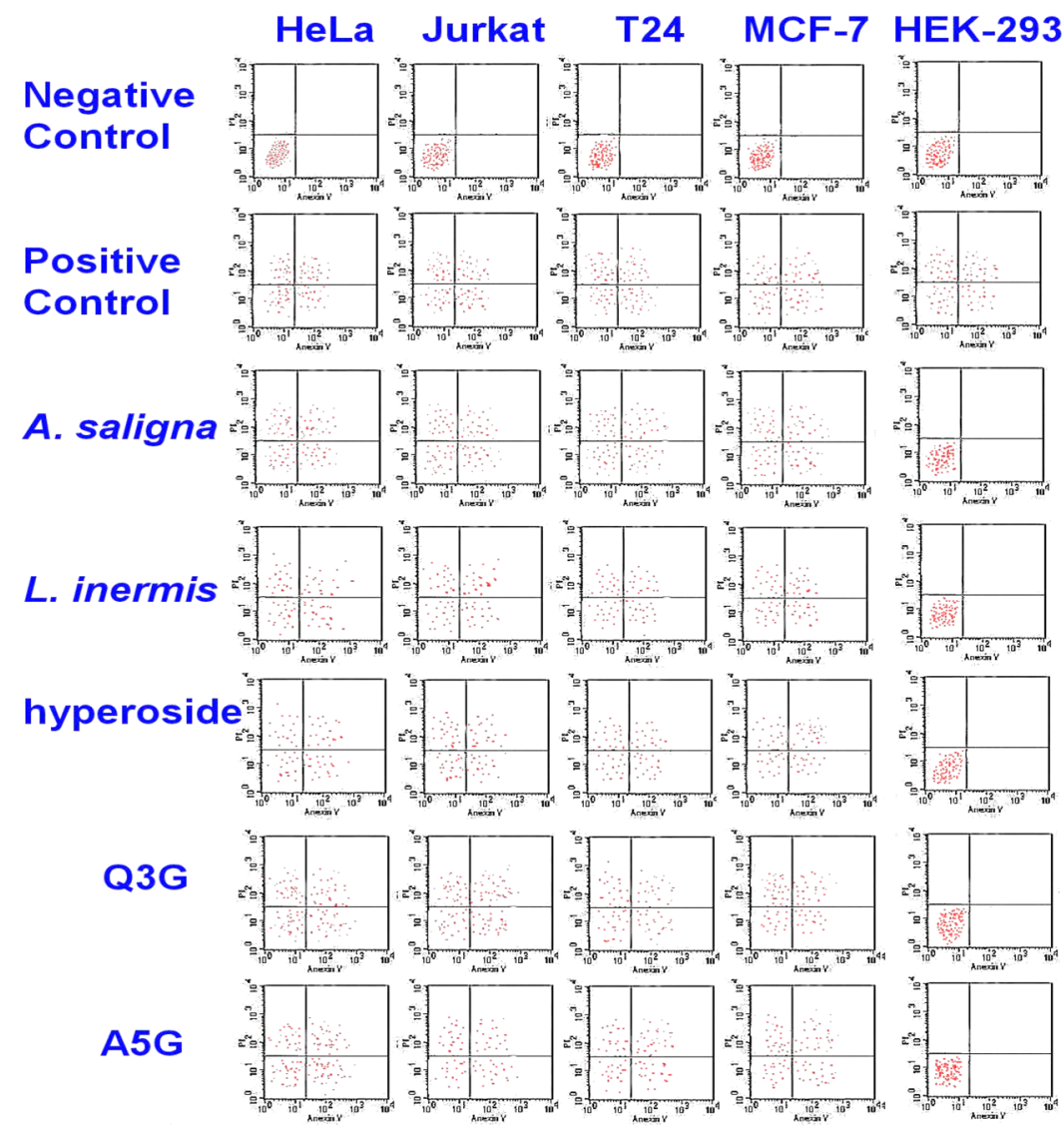

Figure 4. Cytotoxicity of A. saligna and L. inermis methanolic extracts, hyperoside, quercetin 3-glucuronide (Q3G) and apigenin 5-glucoside (A5G), as estimated with flow cytometry. There was an accumulation of early apoptotic cells in the lower-right quadrant as well as accumulation of the late apoptotic cell in the upper-right quadrant in treated cancer cells. 


\subsection{ROS Accumulation}

A. saligna and L. inermis leaf extracts as well as hyperoside, apigenin 5-glucoside and quercetin 3-glucuronide significantly reduced the ROS accumulation in all investigated cancer cells compared to controls using the intercelleular ROS accumulation assay of $\mathrm{H}_{2}$ DCFDA fluorescence (Figure 5). The highest reduction of ROS was achieved using apigenin 5-glucoside (A5G) in Jurkat, T24 and MCF-7 following 90 min of incubation. $\mathrm{H}_{2} \mathrm{O}_{2}$ showed the highest levels of $\mathrm{ROS}$ accumulation in all cancer cells.

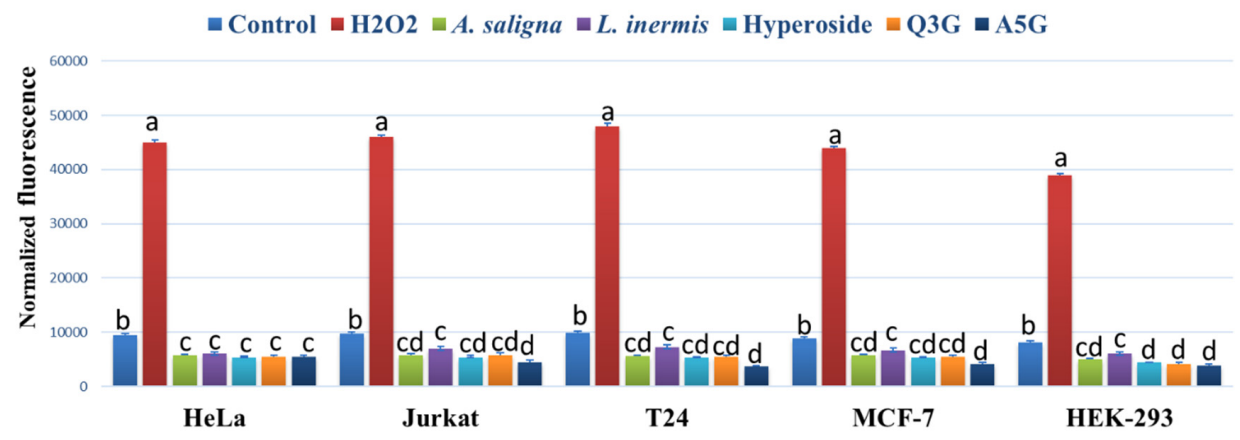

Figure 5. The effect of $A$. saligna and L. inermis methanolic extracts, hyperoside, quercetin 3-glucuronide (Q3G), and apigenin 5-glucoside (A5G) DPPH IC 50 on the $2^{\prime}, 7^{\prime}$-dichlorofluorescein (DCF) fluorescence in HeLa, Jurkat, T24, MCF-7 and HEK-293 cells. A medium with $1 \mathrm{mM}$ hydrogen peroxide $\left(\mathrm{H}_{2} \mathrm{O}_{2}\right)$ was used as a positive control. The data are expressed as the mean $\pm \mathrm{SD}$ of three experiments (four replicates per treatment). Different letters among group of columns indicate significant differences $(p \leq 0.05)$.

\subsection{Antibacterial Activities of A. saligna and L. inermis Leaf Extracts}

A. saligna and L. inermis extracts showed antibacterial effects against different bacteria (Table 2). A. saligna showed two-fold higher antibacterial activities than L. inermis against all bacteria. The most sensitive bacteria were $E$. coli and $S$. aureus (showing the lowest $\mathrm{IC}_{50}$ values), while the most resistant were L. monocytogenes and $M$. flavus. Identified polyphenols including rutoside, apigenin 5-glucoside and $p$-coumaric acid showed strong antibacterial activities against all bacteria except hyperoside, quercetin and quercetin 3-glucuronide, showing moderate to low antibacterial effects.

Table 2. Antibacterial effects of A. saligna and L. inermis methanolic extracts, rutoside, hyperoside and apigenin 5-glucoside, $p$-coumaric acid, quercetin and quercetin 3-glucuronide by means of minimum inhibitory (MIC) and bactericidal concentration (MBC) in $\mathrm{mg} / \mathrm{mL}$. Values are the means of three replicates.

\begin{tabular}{ccccccc}
\hline & $\begin{array}{c}\text { B. cereus MIC } \\
\text { MBC }\end{array}$ & $\begin{array}{c}\text { P. aeruginosa } \\
\text { MIC MBC }\end{array}$ & $\begin{array}{c}\text { L. monocytogenes } \\
\text { MIC MBC }\end{array}$ & $\begin{array}{c}\text { E. coli MIC } \\
\text { MBC }\end{array}$ & $\begin{array}{c}\text { M. flavus MIC } \\
\text { MBC }\end{array}$ & $\begin{array}{c}\text { S. aureus MIC } \\
\text { MBC }\end{array}$ \\
\hline A. saligna & $0.35 \pm 0.01$ & $0.37 \pm 0.02$ & $0.47 \pm 0.03$ & $0.31 \pm 0.03$ & $0.41 \pm 0.02$ & $0.30 \pm 0.05$ \\
& $0.73 \pm 0.03$ & $0.79 \pm 0.03$ & $0.99 \pm 0.05$ & $0.72 \pm 0.01$ & $0.85 \pm 0.03$ & $0.73 \pm 0.03$ \\
\hline L. inermis & $0.43 \pm 0.03$ & $0.41 \pm 0.03$ & $0.42 \pm 0.03$ & $0.34 \pm 0.02$ & $0.52 \pm 0.05$ & $0.41 \pm 0.02$ \\
& $0.86 \pm 0.04$ & $0.96 \pm 0.05$ & $0.93 \pm 0.02$ & $0.75 \pm 0.03$ & $1.53 \pm 0.12$ & $0.93 \pm 0.03$ \\
\hline Rutoside & $0.11 \pm 0.01$ & $0.07 \pm 0.01$ & $0.11 \pm 0.01$ & $0.12 \pm 0.01$ & $0.12 \pm 0.01$ & $0.11 \pm 0.01$ \\
& $0.22 \pm 0.01$ & $0.12 \pm 0.01$ & $0.21 \pm 0.02$ & $0.23 \pm 0.01$ & $0.23 \pm 0.01$ & $0.25 \pm 0.03$ \\
\hline Hyperoside & $23.3 \pm 2.4$ & $27.2 \pm 3.53$ & $34.3 \pm 4.21$ & $31.2 \pm 1.43$ & $22.42 \pm 1.55$ & $19.54 \pm 2.41$ \\
& $>500$ & $>500$ & $>500$ & $>500$ & $>500$ & $>500$ \\
\hline Apigenin & $0.13 \pm 0.01$ & $0.12 \pm 0.01$ & $0.10 \pm 0.01$ & $0.09 \pm 0.01$ & $0.10 \pm 0.01$ & $0.13 \pm 0.02$ \\
5-glucoside & $0.33 \pm 0.03$ & $0.31 \pm 0.03$ & $0.28 \pm 0.02$ & $0.27 \pm 0.03$ & $0.30 \pm 0.03$ & $0.33 \pm 0.03$ \\
\hline p-Coumaric & $0.12 \pm 0.01$ & $0.06 \pm 0.01$ & $0.26 \pm 0.02$ & $0.12 \pm 0.01$ & $0.16 \pm 0.02$ & $0.23 \pm 0.02$ \\
acid & $0.31 \pm 0.03$ & $0.22 \pm 0.02$ & $0.58 \pm 0.03$ & $0.25 \pm 0.02$ & $0.38 \pm 0.03$ & $0.47 \pm 0.03$ \\
\hline \multirow{2}{*}{ Quercetin } & $30.6 \pm 3.1$ & $31.8 \pm 2.11$ & $43.7 \pm 3.51$ & $38.6 \pm 3.14$ & $28.65 \pm 2.11$ & $21.53 \pm 1.53$ \\
& $>500$ & $>500$ & $>500$ & $>500$ & $>500$ & $>500$ \\
\hline Quercetin & $35.2 \pm 3.1$ & $25.3 \pm 1.54$ & $32.1 \pm 3.78$ & $31.8 \pm 3.32$ & $21.65 \pm 2.11$ & $17.1 \pm 1.53$ \\
3-glucuronide & $>500$ & $315.14 \pm 18.42$ & $>500$ & $>500$ & $411.17 \pm 22.67$ & $427 \pm 27.23$ \\
\hline Streptomycin & $0.07 \pm 0.01$ & $0.11 \pm 0.01$ & $0.12 \pm 0.01$ & $0.11 \pm 0.01$ & $0.10 \pm 0.01$ & $0.15 \pm 0.01$ \\
& $0.16 \pm 0.02$ & $0.21 \pm 0.02$ & $0.21 \pm 0.02$ & $0.20 \pm 0.01$ & $0.21 \pm 0.02$ & $0.31 \pm 0.02$ \\
\hline
\end{tabular}




\subsection{Antifungal Effects of Leaf Extracts}

A. saligna and L. inermis extracts showed strong antifungal effects against most fungi studied (Table 3). A. saligna showed two to three-fold higher activity (lower $\mathrm{IC}_{50}$ values) than L. inermis. Rutoside, hyperoside, apigenin 5-glucoside and $p$-coumaric acid showed the highest antifungal effects among the studied polyphenols.

Table 3. Minimum inhibitory (MIC) and fungicidal concentration (MFC) of A. saligna and L. inermis methanolic extracts, rutoside, hyperoside, apigenin 5-glucoside, quercetin, quercetin 3-glucuronide and $p$-coumaric acid. Values are means of three replicates in $\mathrm{mg} / \mathrm{mL}$.

\begin{tabular}{ccccccc}
\hline & $\begin{array}{c}\text { Aspergillus } \\
\text { flavus } \\
\text { MIC MFC }\end{array}$ & $\begin{array}{c}\text { Aspergillus } \\
\text { ochraceus } \\
\text { MIC MFC }\end{array}$ & $\begin{array}{c}\text { Aspergillus } \\
\text { niger } \\
\text { MIC MFC }\end{array}$ & $\begin{array}{c}\text { Candida } \\
\text { albicans } \\
\text { MIC MFC }\end{array}$ & $\begin{array}{c}\text { Penicillium } \\
\text { funiculosum } \\
\text { MIC MFC }\end{array}$ & $\begin{array}{c}\text { Penicillium } \\
\text { ochrochloron } \\
\text { MIC MFC }\end{array}$ \\
\hline A. saligna & $0.30 \pm 0.02$ & $0.38 \pm 0.02$ & $0.48 \pm 0.03$ & $0.58 \pm 0.03$ & $0.43 \pm 0.03$ & $0.44 \pm 0.05$ \\
& $0.91 \pm 0.05$ & $0.95 \pm 0.3$ & $1.02 \pm 0.05$ & $1.42 \pm 0.18$ & $1.01 \pm 0.06$ & $1.31 \pm 0.12$ \\
\hline L. inermis & $0.45 \pm 0.05$ & $0.47 \pm 0.03$ & $0.64 \pm 0.05$ & $0.88 \pm 0.04$ & $0.75 \pm 0.02$ & $0.79 \pm 0.03$ \\
& $0.98 \pm 0.06$ & $1.07 \pm 0.05$ & $1.45 \pm 0.17$ & $1.86 \pm 0.13$ & $1.53 \pm 0.05$ & $1.64 \pm 0.12$ \\
\hline Rutoside & $0.21 \pm 0.02$ & $0.18 \pm 0.01$ & $0.28 \pm 0.03$ & $0.25 \pm 0.03$ & $0.30 \pm 0.02$ & $0.23 \pm 0.03$ \\
& $0.45 \pm 0.03$ & $0.55 \pm 0.03$ & $0.62 \pm 0.03$ & $0.51 \pm 0.03$ & $0.71 \pm 0.03$ & $0.43 \pm 0.03$ \\
\hline Hyperoside & $0.10 \pm 0.02$ & $0.13 \pm 0.03$ & $0.15 \pm 0.03$ & $0.21 \pm 0.03$ & $0.25 \pm 0.03$ & $0.31 \pm 0.03$ \\
& $0.46 \pm 0.03$ & $0.50 \pm 0.05$ & $0.52 \pm 0.04$ & $0.93 \pm 0.07$ & $1.03 \pm 0.11$ & $1.19 \pm 0.10$ \\
\hline Apigenin & $0.11 \pm 0.03$ & $0.17 \pm 0.02$ & $0.23 \pm 0.03$ & $0.03 \pm 0.01$ & $0.75 \pm 0.05$ & $0.59 \pm 0.05$ \\
5-glucoside & $0.84 \pm 0.04$ & $1.03 \pm 0.08$ & $1.11 \pm 0.15$ & $0.08 \pm 0.01$ & $1.33 \pm 0.14$ & $1.26 \pm 0.13$ \\
\hline Quercetin & $0.31 \pm 0.03$ & $0.20 \pm 0.02$ & $0.21 \pm 0.01$ & $0.06 \pm 0.01$ & $0.24 \pm 0.03$ & $0.29 \pm 0.03$ \\
& $0.63 \pm 0.05$ & $0.75 \pm 0.03$ & $0.75 \pm 0.02$ & $0.33 \pm 0.03$ & $0.70 \pm 0.04$ & $0.63 \pm 0.03$ \\
\hline Quercetin & $0.26 \pm 0.03$ & $0.17 \pm 0.03$ & $0.18 \pm 0.02$ & $0.06 \pm 0.01$ & $0.21 \pm 0.01$ & $0.26 \pm 0.02$ \\
3-glucuronide & $0.52 \pm 0.03$ & $0.61 \pm 0.05$ & $0.62 \pm 0.05$ & $0.27 \pm 0.03$ & $0.60 \pm 0.05$ & $0.54 \pm 0.05$ \\
\hline p-Coumaric & $0.22 \pm 0.03$ & $0.23 \pm 0.02$ & $0.21 \pm 0.01$ & $0.32 \pm 0.03$ & $0.22 \pm 0.01$ & $0.20 \pm 0.02$ \\
acid & $0.43 \pm 0.01$ & $0.45 \pm 0.05$ & $0.41 \pm 0.03$ & $0.60 \pm 0.01$ & $0.59 \pm 0.05$ & $0.40 \pm 0.03$ \\
\hline KTZ & $0.20 \pm 0.01$ & $0.23 \pm 0.02$ & $0.10 \pm 0.01$ & $0.22 \pm 0.01$ & $2.05 \pm 0.13$ & $0.21 \pm 0.01$ \\
(Ketoconazole) & $0.41 \pm 0.03$ & $0.46 \pm 0.03$ & $0.21 \pm 0.03$ & $0.43 \pm 0.02$ & $3.51 \pm 0.11$ & $0.43 \pm 0.05$ \\
\hline
\end{tabular}

\section{Discussion}

Few studies have investigated the phenolic acid and flavonoid composition of $A$. saligna and L. inermis leaf extracts. This is the first study to quantitatively determine compounds from phenolic acids and flavonoids in Saudi A. saligna and L. inermis natural populations (Table 1). The main polyphenols were rutoside (1533.0 mg/100 g DW), hyperoside (quercetin 3-galactoside) $(632.5 \mathrm{mg} / 100 \mathrm{~g}$ DW), quercetin 3-glucuronide (125.5 mg/100 g DW), isoquercetin $(73.2 \mathrm{mg} / 100 \mathrm{~g}$ DW) and quercetin $(6.1 \mathrm{mg} / 100 \mathrm{~g} \mathrm{DW})$. In A. saligna leaf extracts, high amounts of gallic acid (136.2 q) and $p$-coumaric acid $(34.8 \mathrm{mg} / 100 \mathrm{~g} \mathrm{DW})$ were also confirmed for the first time in the context of Arabian-origin plants. El Sissi et al. [16] isolated the flavonoids: quercitrin, astragalin, myricitrin and kaempferol as well as quercetin from the leaves of A. saligna growing in Cairo (Egypt), which were found also in our samples. El-Toumy et al. [17] studied the ethyl-acetate extract of of A. saligna leaves harvested from Cairo (Egypt) for phenolic compound detection. They confirmed structures similar to our Arabian origin samples: gallic acid, quercetin, quercetin 3-arabinoside, quercetin 3-rhamnoside, and additionally: apigenin, apigenin 7-glucoside, catechin, 7-galloylcatechin, myricetin 3-rhamnoside, myricetin 3-arabinoside, myricetin 3-glucopyranoside, luteolin and myricetin. A. saligna leaf extracts cultivated in Damietta City (Egypt) were studied by Sahar et al. [42] for pirostane saponin as well as biflavonoid glycoside. They detected some flavonoids including myricetin 3-rhamnoside, erythrodiol and quercetin 3-rhamnoside. Recently, Al-Huqail et al. [18] studied the Egyptian A. saligna flower extracts for antifungal, antibacterial and antioxidant activities. They performed HPLC analyses of flower water extracts and detected benzoic acid (161.68 mg/100 g DW), caffeic acid (100.11 mg/100 g DW), o-coumaric acid (42.09 mg/100 g DW), p-hydroxybenzoic acid (14.13 mg/100 g DW), ellagic acid $(12.17 \mathrm{mg} / 100 \mathrm{~g})$, naringenin $(145.03 \mathrm{mg} / 100 \mathrm{~g} \mathrm{DW})$, quercetin $(111.96 \mathrm{mg} / 100 \mathrm{~g} \mathrm{DW})$ and kaempferol (44.49 mg/100 g DW). In the current study, the methanolic leaf extracts contained quercetin 
in comparable amounts to those found previously in the flower water extracts. Dube et al. [43] studied five Southern Africa Acacia species (A. karroo, A. nilotica, A. senegal, A. eriolaba and Faidherbia albida) aceton:water $(7: 3, v / v)$ leaf extracts for their proanthocyanidin content; however they performed only general spectrophotometric assays, and they did not study A. saligna. A. karroo showed the highest and A. senegal the lowest phenolic compound contents based on Folin-Ciocalteu assay.

The methanolic leaf extracts of L. inermis growing in Northern Saudi Arabia investigated in the current study contained high amounts of apigetrin, at $1180.9 \mathrm{mg} / 100 \mathrm{~g}$ DW; apigenin 5-glucoside, at $596.3 \mathrm{mg} / 100 \mathrm{~g} \mathrm{DW}$; as well as gallic acid, at $81.0 \mathrm{mg} / 100 \mathrm{~g}$ DW (Table 1 and Figure 1B). Phenolic compounds, including flavonoids, tannins, coumarins, and naphthoquinones, are particularly abundant ingredients of L. inermis leaf extracts [22]. Mikhaeil et al. [44] studied the Egyptian L. inermis leaf extracts and detected $p$-coumaric acid from phenolic acids and, similar to our samples, apigenin and apigetrin (cosmosiin) from flavonoids. The apigenin derivative $4^{\prime}$-methoxyapigenin (linarigenin, linarisenin) was also detected by Mahmoud et al. in L. inermis leaf extracts of Egyptian origin [45]. Gallic acid was confirmed by other scientists from Iran [46]. Moreover, the presence of $p$-coumaric acids was reported by Mikhaeil et al. [44], but this compound was not detected in the Saudi Arabian henna leaf extract.

Leaf extracts of A. saligna and L. inermis showed strong antioxidant effects using different assays. A. saligna showed higher antioxidant effects compared to L. inermis. The higher antioxidant effects of A. saligna can mainly be attributed to the polyphenolic composition of leaves, including hyperoside, quercetin 3-glucuronide, gallic acid, p-coumaric acid, quercitrin and rutoside. These polyphenols showed strong antioxidant activities when examined individually. In agreement with the current study, a previous investigation on polyphenols showed that hyperoside has comparable antioxidant activities to other polyphenols, such as caffeic and ellagic acids [47]. Quercetin, as a flavonoid glycoside, is common in plants and in the human diet, reduces ROS production and may stimulate THP-1 acute monocytic leukemia in vitro [48]. Previous investigation found that quercetin has antioxidant and antiproliferative activities against RAW264.7 cancer Cells [49]. In the current study, we found strong quercetin 3-glucuronide antioxidant activities using different assays, and this is the first study exploring the antioxidant and biological activities of this quercetin derivative. Gallic acid (3,4,5-trihydroxybenzoic acid) is a known triphenolic compound that has strong antioxidant activities, as found in this study [50]. It was found that $p$-coumaric acid is a strong antioxidant, which is in agreement with previous investigations [51,52]. In L. inermis, moderate antioxidant activities were found, and these were attributed to the polyphenolic composition of leaf extracts including apigenin 5-glucoside. Apigenin has in vitro and in vivo antioxidant effects, as well as anti-mutagenic and anti-inflammatory effects, by inhibiting the cell cycle, inducing apoptosis and diminishing oxidative stress [53]. This is the first study to investigate the antioxidant and biological activities of the apigenin-derivative apigenin 5-glucoside and to show strong antioxidant activities.

Few studies have investigated the antioxidant activities of Acacia species; for example, Egyptian A. saligna flower water extracts showed weak antioxidant and antibacterial activities but had good antifungal activity against Penicillium chrysogenum using the disc diffusion method [18]. In another study, the Egyptian Acacia nilotica and Acacia seyal leaf extracts showed higher antioxidant activities than Acacia laeta extracts [19]. To our best knowledge, this is the first investigation on the antioxidant activities of Saudi A. saligna. In Tunisian L. inermis, the butanolic fraction showed strong antioxidant activities, and these activities were attributed to phenolic glycosides including 1,2,4-Trihydroxynaphthalene-1-O- $\beta$-d-glucopyranoside [23]. In another study, Tunisian L. inermis leaf and seed aqueous extracts showed antioxidant activities, but no active compounds were identified [24]. The Iranian L. inermis aqueous leaf extracts (Henna leaves) showed diverse antioxidant activities associated with ecotypes [25].

MTT and flow cytometry assays revealed that $A$. saligna and L. inermis leaf extracts have antiproliferative and cytotoxic activities against different cancer cells. These activities were attributed to the polyphenolic composition including rutoside, hyperoside, quercetin, quercetin 3-glucuronide and 
p-coumaric acid. Rutoside (rutin) has known antiproliferative and cytotoxic activities against different cancer cells [54]. A previous investigation showed that hyperoside has anticancer activity against lung cancer cells by upregulating FoxO1 via CCAT1 [55]; additionally, it showed an inhibitory effect against SW620 human colorectal cancer cells via the induction of the p.53 signaling pathway and apoptosis [56]. Apigenin (4',5,7-trihydroxyflavone) is a common component of the human diet, especially in fruits, vegetables and herbs, with known antiproliferative and proapoptotic bioactivity [57]. The current study is the first to report on the antiproliferative and cytotoxic activities of the apigenin derivative apigenin 5-glucoside.

Gallic acid showed strong antiproliferative activities against the different cancer cells examined in this study, which is in agreement with previous investigations [50]. Gallic acid obtained from mango peels has antiproliferative effects against human colon adenocarcinoma cells and mouse connective cells, which can be attributed to its antioxidant activities [50]. Quercetin is recognized as an antiproliferative factor against specific cancer cells and has been shown to reduce the activity of specificity protein 1 and minimize the proliferation of human carcinoma HepG2 cells [57,58]. Quercetin has antiproliferative activities against prostate cancer cells, which can be attributed to its synergy with other polyphenols in green tea [58]. In addition, quercetin has cytotoxic activity against lung cancer cells [59]. In the current study, quercetin 3-glucuronide (quercetin derivative) was shown for the first time to exhibit antiproliferative and cytotoxic activities against different cancer cells. Cytotoxic spirostane saponin and biflavonoid glycoside were identified in the leaves of Egyptian A. saligna and showed anticancer activities against HepG2 cancer cells [42]. A previous investigation on the aerial parts of Acacia species (A. salicina, A. laeta, A. hamulosa, and A. tortilis) from the eastern region of Saudi Arabia (approximately $700-1000 \mathrm{~km}$ from the Riyadh region) revealed that $A$. laeta and $A$. hamulosa have cytotoxic activities against HepG2 and breast cancer cell line [20]. In a previous investigation, leaf aqueous and methanolic extracts of Indian L. inermis showed significant antioxidant activities that inhibited Cr (VI)-induced cytotoxicity in MDA-MB-435S breast cancer cells, and these activities were associated with phenolic compounds including gallic acid and p-hydroxybenzoic acid [26].

A. saligna and L. inermis leaf extracts had antibacterial effects against most bacteria investigated. A. saligna exhibited two-fold higher antibacterial activities than L. inermis against all bacteria. The most sensitive bacteria were E. coli and S. aureus. Identified polyphenols (rutoside, apigenin 5-glucoside and $p$-coumaric acid) showed comparable antibacterial activities to the standards. A previous investigation on Egyptian A. saligna showed that flower water extracts had weak antibacterial activities but good antifungal activity against Penicillium chrysogenum using the disc diffusion method [18]. In another investigation, A. saligna from Egyptian methanolic leaf extract exhibited no antibacterial activities against most bacteria examined [17]. Another study on the aerial parts of other Acacia species revealed that A. laeta and A. tortilis have antimicrobial activities against S. aureus, E. coli, and P. aeruginosa [20]. Tunisian L. inermis leaf and seed aqueous extracts showed antimicrobial activities, but no active compounds were identified [24]. Iranian L. inermis aqueous leaf extracts showed strong antibacterial activities against $S$. aureus, Streptococcus agalactiae, B. cereus, Corynebacterium pseudotuberculosis, Klebsiella pneumonia, E. coli and Salmonella enterica serovar typhi [25]. However, no active compounds were identified. The antibacterial activities of $A$. saligna and L. inermis found in this study are attributed to the moderate to high contents of polyphenols such as rutoside, apigenin 5-glucoside and $p$-coumaric acid. Rutoside (rutin) has known antibacterial activities against E. coli, Proteus vulgaris, Shigella sonnei, P. auruginosssa and B. subtilis [54]. Apigenins such as aglycone have antibacterial activity against $E$. coli and P. aeruginosa [60]; however, this is the first report on the wide-spectrum biological activities of apigenin 5-glucoside. $P$-coumaric acid exhibited antibacterial activity against $B$. cereus and Salmonella typhimurium when applied with niacin [61]. In the current study, we found moderate antibacterial activities of hyperoside, quercetin and quercetin 3-glucuronide. Quercetin showed moderate antibacterial activities against S. aureusm, E. coli and P. aeruginosa in previous investigations $[62,63]$. 
A. saligna and L. inermis extracts showed strong antifungal effects against most fungi studied (Table 3). A. saligna showed two to three-fold higher activity (lower $\mathrm{IC}_{50}$ values) than L. inermis. Rutoside, hyperoside, apigenin 5-glucoside and $p$-coumaric acid showed the highest antifungal effects among the studied polyphenols.

A. saligna and L. inermis extracts showed strong antifungal effects against the studied fungi. A. saligna showed two to three-fold higher activity than L. inermis. The identified polyphenols including rutoside, hyperoside, apigenin 5-glucoside and $p$-coumaric acid showed the highest antifungal activities, explaining the activities of leaf extracts. A previous investigation on Egyptian A. saligna showed that flower water extracts had good antifungal activity against Penicillium chrysogenum using the disc diffusion method [18]. A study on the aerial parts of other Acacia species revealed that A. laeta and A. tortilis have antifungal activities against $C$. albicans [20]. Chinese Acacia confuse seeds contained a protein showing strong antifungal activities against Rhizoctonia solani [64]. Apigenin 5-glucoside showed strong antifungal activities against $C$. albicans in the current study, which were comparable or greater than those of apigenin and its derivatives found previously [65]. These antifungal activities were attributed to the reduction of intra and extracellular reactive oxidative species as a mechanism of antifungal action. The current study is the first comprehensive illustration of the fungicidal activities of the apigenin-derivative apigenin 5-glucoside. Rutoside has antifungal activities against $C$. albicans [54]. A previous investigation showed that hyperoside had antifungal activities against Alternaria alternata, Pestalotia guepinii, Fusarium avenaceum, Drechslera sp. and Epicoccum nigrum [66]. P-coumaric acid showed antifungal effects against Botrytis cinerea [67]. Quercetin has antifungal activities against C. albicans [68-70]. However, this is the first report on the antifungal activities of apigenin 5-glucoside.

\section{Conclusions}

To the best of our knowledge, this is the first study to explore the polyphenol composition and biological activities of methanolic leaf extracts of natural $A$. saligna and L inermis populations from northern Saudi Arabia. Several polyphenols were tentatively identified in the leaf extracts including rutoside, hyperoside, gallic acid, quercetin 3-glucuronide and $p$-coumaric acid in A. saligna and apigetrin, apigenin 5-glucoside and gallic acid in L. inermis. Indeed, further analyses are needed to better understand the complete composition of the studied plants. The MTT and flow cytometry assays revealed that $A$. saligna and L. inermis leaf extracts had antiproliferative and cytotoxic activities against different cancer cells. These activities were attributed to the polyphenolic composition, including rutoside, hyperoside, quercetin, quercetin 3-glucuronide and $p$-coumaric acid, and necrotic cell accumulation during apoptotic periods. Leaf extracts of A. saligna and L. inermis showed strong antioxidant effects using different assays. A. saligna showed higher antioxidant effects compared to L. inermis. The higher antioxidant effects of $A$. saligna can mainly be attributed to the polyphenolic composition of leaves, including hyperoside, quercetin 3-glucuronide, gallic acid, $p$-coumaric acid, quercitrin and rutoside. A. saligna and L. inermis leaf extracts had antibacterial effects against most bacteria investigated. A. saligna had twice higher antibacterial activities than L. inermis against all bacteria. The most sensitive bacteria were E. coli and S. aureus. The identified polyphenols (rutoside, apigenin 5-glucoside, and $p$-coumaric acid) showed comparable antibacterial activities to the standards. Both species exhibited antifungal activities, which were attributed to their polyphenol composition and associated with specific polyphenols including rutoside, hyperoside, apigenin 5-glucoside and $p$-coumaric acid. The current study is the first to report on the antiproliferative, cytotoxic, antibacterial and antifungal activities of the apigenin-derivative apigenin 5-glucoside.

Supplementary Materials: The following are available online at http://www.mdpi.com/2223-7747/9/7/908/s1.

Author Contributions: Conceptualization, H.O.E., A.S. and F.A.A.-M.; Data curation, H.O.E. and F.A.A.-M.; Formal analysis, A.S. and H.E.; Funding acquisition, H.O.E., H.E. and A.S.; Investigation, H.O.E., A.S., P.K., F.A.A.-M. and M.A.A.-Y.; Methodology, A.S., P.K. and M.A.A.-Y.; Project administration, P.K. and M.A.A.-Y.; Resources, H.E., F.A.A.-M. and M.A.A.-Y.; Visualization, A.S., P.K.; Writing-original draft, H.O.E., A.S.; Writing-review \& editing, H.O.E., A.S., H.E. All authors have read and agreed to the published version of the manuscript. 
Funding: This publication was financially supported by the Deanship of Scientific Research at King Saud University through research group number RG-1440-12.

Acknowledgments: The authors extend their appreciation to the Deanship of Scientific Research at King Saud University for their financial support of the present research manuscript, research group number RG-1440-12.

Conflicts of Interest: The authors declare no conflict of interest.

\section{References}

1. Organization, W.H. WHO Traditional Medicine Strategy: 2014-2023; WHO Press: Geneva, Switzerland, 2013. Available online: https://apps.who.int/iris/bitstream/handle/10665/92455/9786167697581-tha.pdf (accessed on 16 July 2020).

2. Queen, B.; Tollefsbol, T. Polyphenols and Aging. Curr. Aging Sci. 2010, 3, 34-42. [CrossRef] [PubMed]

3. Su, B.; Wang, X.; Nunomura, A.; Moreira, P.I.; Lee, H.G.; Perry, G.; Smith, M.A.; Zhu, X. Oxidative stress signaling in Alzheimer's disease. Curr. Alzheimer. Res. 2008, 5, 525-532. [CrossRef] [PubMed]

4. Wu, M.; Luo, Q.; Nie, R.; Yang, X.; Tang, Z.; Chen, H. Potential implications of polyphenols on aging considering oxidative stress, inflammation, autophagy, and gut microbiota. Crit. Rev. Food Sci. Nutr. 2020, 1-19. [CrossRef] [PubMed]

5. Elansary, H.O.; Szopa, A.; Kubica, P.; Al-Mana, F.A.; Mahmoud, E.A.; El-Abedin, T.K.A.Z.; Mattar, M.A.; Ekiert, H. Phenolic Compounds of Catalpa speciosa, Taxus cuspidata, and Magnolia acuminata have Antioxidant and Anticancer Activity. Molecules 2019, 24, 412. [CrossRef] [PubMed]

6. Elansary, O.H.; Szopa, A.; Kubica, P.; Ekiert, H.; Mattar, M.A.; Al-Yafrasi, A.M.; El-Ansary, O.D.; Zin El-Abedin, K.T.; Yessoufou, K. Polyphenol Profile and Pharmaceutical Potential of Quercus spp. Bark Extracts. Plants 2019, 8, 486. [CrossRef] [PubMed]

7. Saleh, A.; ElFayoumi, H.M.; Youns, M.; Barakat, W. Rutin and orlistat produce antitumor effects via antioxidant and apoptotic actions. Naunyn. Schmiedebergs Arch. Pharmacol. 2019, 392, 165-175. [CrossRef] [PubMed]

8. Yoo, T.-K.; Kim, J.-S.; Hyun, T.K. Polyphenolic Composition and Anti-Melanoma Activity of White Forsythia (Abeliophyllum distichum Nakai) Organ Extracts. Plants 2020, 9, 757. [CrossRef]

9. Gutiérrez-Grijalva, E.P.; Picos-Salas, M.A.; Leyva-López, N.; Criollo-Mendoza, M.S.; Vazquez-Olivo, G.; Heredia, J.B. Flavonoids and Phenolic Acids from Oregano: Occurrence, Biological Activity and Health Benefits. Plants 2018, 7, 2. [CrossRef]

10. Okla, K.M.; Alamri, A.S.; Salem, Z.M.M.; Ali, M.H.; Behiry, I.S.; Nasser, A.R.; Alaraidh, A.I.; Al-Ghtani, M.S.; Soufan, W. Yield, Phytochemical Constituents, and Antibacterial Activity of Essential Oils from the Leaves/Twigs, Branches, Branch Wood, and Branch Bark of Sour Orange (Citrus aurantium L.). Processes 2019, 7, 363. [CrossRef]

11. Salem, M.Z.M.; Elansary, H.O.; Ali, H.M.; El-Settawy, A.A.; Elshikh, M.S.; Abdel-Salam, E.M.; Skalicka-Wozniak, K. Bioactivity of essential oils extracted from Cupressus macrocarpa branchlets and Corymbia citriodora leaves grown in Egypt. BMC Complement. Altern. Med. 2018, 18, 23. [CrossRef]

12. Khan, M.; Siddiqui, S.A. Concurrent chemoradiotherapy with or without induction chemotherapy for the management of cervical lymph node metastasis from unknown primary tumor. J. Cancer Res. Ther. 2018, 14, 1117-1120. [CrossRef] [PubMed]

13. Elansary, H.; Szopa, A.; Kubica, P.; Ekiert, H.; El-Ansary, D.; Al-Mana, F.; Mahmoud, E. Polyphenol Content and Biological Activities of Ruta graveolens L. and Artemisia abrotanum L. in Northern Saudi Arabia. Processes 2020, 8, 531. [CrossRef]

14. Elansary, H.O.; Szopa, A.; Klimek-Szczykutowicz, M.; Jafernik, K.; Ekiert, H.; Mahmoud, E.A.; Barakat, A.A.; El-Ansary, D.O. Mammillaria Species-Polyphenols Studies and Anti-Cancer, Anti-Oxidant, and Anti-Bacterial Activities. Molecules 2019, 25, 131. [CrossRef] [PubMed]

15. Adiamo, O.Q.; Netzel, M.E.; Hoffman, L.C.; Sultanbawa, Y. Acacia seed proteins: Low or high quality? A comprehensive review. Compr. Rev. Food Sci. Food Saf. 2020, 19, 21-43. [CrossRef]

16. El Sissi, H.I.; El Sherbeiny, A.E.A. The flavanoid components of the leaves of Acacia saligna. Qual. Plant. Mater. Veg. 1967, 14, 257-266. [CrossRef]

17. El-Toumy, S.; Salib, J.; Mohamed, W.; Morsy, F. Phytochemical and antimicrobial studies on Acacia Saligna Leaves. Egypt. J. Chem. 2010, 53, 705. 
18. Al-Huqail, A.A.; Behiry, S.I.; Salem, M.Z.M.; Ali, H.M.; Siddiqui, M.H.; Salem, A.Z.M. Antifungal, Antibacterial, and Antioxidant Activities of Acacia Saligna (Labill.) H. L. Wendl. Flower Extract: HPLC Analysis of Phenolic and Flavonoid Compounds. Molecules 2019, 24, 700. [CrossRef]

19. Abdel-Farid, I.B.; Sheded, M.G.; Mohamed, E.A. Metabolomic profiling and antioxidant activity of some Acacia species. Saudi. J. Biol. Sci. 2014, 21, 400-408. [CrossRef]

20. Alajmi, M.F.; Alam, P.; Alqasoumi, S.I.; Ali Siddiqui, N.; Basudan, O.A.; Hussain, A.; Mabood Husain, F.; Ali Khan, A. Comparative anticancer and antimicrobial activity of aerial parts of Acacia salicina, Acacia laeta, Acacia hamulosa and Acacia tortilis grown in Saudi Arabia. Saudi Pharm. J. 2017, 25, 1248-1252. [CrossRef]

21. Abd-ElGawad, A.; El-Amier, Y. Allelopathy and Potential Impact of Invasive Acacia saligna (Labill.) Wendl. on Plant Diversity in the Nile Delta Coast of Egypt. Int. J. Environ. Res. 2015, 9, 923-932.

22. Badoni Semwal, R.; Semwal, D.K.; Combrinck, S.; Cartwright-Jones, C.; Viljoen, A. Lawsonia inermis L. (henna): Ethnobotanical, phytochemical and pharmacological aspects. J. Ethnopharmacol. 2014, 155, 80-103. [CrossRef] [PubMed]

23. Hsouna, A.; Trigui, M.; Culioli, G.; Blache, Y.; Jaoua, S. Antioxidant constituents from Lawsonia inermis leaves: Isolation, structure elucidation and antioxidative capacity. Food Chem. 2011, 125, 193-200. [CrossRef]

24. Wiem, A.; Smail, A.; Mnif, W.; Faleiro, M.L.; Miguel, M. Antioxidant, anti-inflammatory and anti-acetylcholinesterase activities of leaf, flower and seed aqueous extracts of Lawsonia inermis from Tunisia. Int. J. Pharm. Pharm. Sci. 2014, 6, 445-452.

25. Pasandi Pour, A.; Farahbakhsh, H. Lawsonia inermis L. leaves aqueous extract as a natural antioxidant and antibacterial product. Nat. Prod. Res. 2019, 1-5. [CrossRef]

26. Guha, G.; Rajkumar, V.; Kumar, R.A.; Mathew, L. Antioxidant Activity of Lawsonia inermis Extracts Inhibits Chromium(VI)-Induced Cellular and DNA Toxicity. Evid.-Based Complement. Altern. Med. eCAM 2011, 2011, 576456. [CrossRef]

27. Elansary, H.O.; Szopa, A.; Kubica, P.; El-Ansary, D.O.; Ekiert, H.; Al-Mana, F.A. Malus baccata var. gracilis and Malus toringoides Bark Polyphenol Studies and Antioxidant, Antimicrobial and Anticancer Activities. Processes 2020, 8, 283. [CrossRef]

28. Ellnain-Wojtaszek, M.; Zgórka, G. High-performance liquid chromatography and thin-layer chromatography of phenolic acids from Ginkgo biloba L. leaves collected within vegetative period. J. Liq. Chromatogr. R. T 1999, 22, 1457-1471. [CrossRef]

29. Sułkowska-Ziaja, K.; Maślanka, A.; Szewczyk, A.; Muszyńska, B. Physiologically Active Compounds in Four Species of Phellinus. Nat. Prod. Commun. 2017, 12, 363-366. [CrossRef]

30. Elansary, H.O.; Yessoufou, K.; Abdel-Hamid, A.M.E.; El-Esawi, M.A.; Ali, H.M.; Elshikh, M.S. Seaweed Extracts Enhance Salam Turfgrass Performance during Prolonged Irrigation Intervals and Saline Shock. Front. Plant Sci. 2017, 8, 10-3389. [CrossRef]

31. Ferreira, J.P.A.; Miranda, I.; Sousa, V.B.; Pereira, H. Chemical composition of barks from Quercus faginea trees and characterization of their lipophilic and polar extracts. PLoS ONE 2018, 13, e0197135. [CrossRef]

32. Elansary, H.O.; Mahmoud, E.A. Egyptian herbal tea infusions' antioxidants and their antiproliferative and cytotoxic activities against cancer cells. Nat. Prod. Res. 2015, 29, 474-479. [CrossRef] [PubMed]

33. Elansary, H.O.; Szopa, A.; Klimek-Szczykutowicz, M.; Ekiert, H.; Barakat, A.A.; Al-Mana, F.A. Antiproliferative, Antimicrobial, and Antifungal Activities of Polyphenol Extracts from Ferocactus Species. Processes 2020, 8, 138. [CrossRef]

34. Elansary, H.O.; Mahmoud, E.A. Basil cultivar identification using chemotyping still favored over genotyping using core barcodes and possible resources of antioxidants. J. Essent. Oil Res. 2015, 27, 82-87. [CrossRef]

35. Nizioł-Łukaszewska, Z.; Furman-Toczek, D.; Zagórska-Dziok, M. Antioxidant activity and cytotoxicity of Jerusalem artichoke tubers and leaves extract on HaCaT and BJ fibroblast cells. Lipids Health Dis. 2018, 17, 280. [CrossRef]

36. Yessoufou, K.; Elansary, H.O.; Mahmoud, E.A.; Skalicka-Wozniak, K. Antifungal, antibacterial and anticancer activities of Ficus drupacea L. stem bark extract and biologically active isolated compounds. Ind. Crop Prod. 2015, 74, 752-758. [CrossRef]

37. Elansary, H.O.; Abdelgaleil, S.A.M.; Mahmoud, E.A.; Yessoufou, K.; Elhindi, K.; El-Hendawy, S. Effective antioxidant, antimicrobial and anticancer activities of essential oils of horticultural aromatic crops in northern Egypt. BMC Complement. Altern. Med. 2018, 18, 214. [CrossRef] 
38. Figueroa, D.; Asaduzzaman, M.; Young, F. Real time monitoring and quantification of reactive oxygen species in breast cancer cell line MCF-7 by $2^{\prime}, 7^{\prime}$-dichlorofluorescin diacetate (DCFDA) assay. J. Pharmacol. Toxicol. Methods 2018, 94, 26-33. [CrossRef]

39. Elansary, H.O.; Szopa, A.; Kubica, P.; Ekiert, H.; Ali, H.M.; Elshikh, M.S.; Abdel-Salam, E.M.; El-Esawi, M.; El-Ansary, D.O. Bioactivities of Traditional Medicinal Plants in Alexandria. Evid. Based Complement. Altern. Med. 2018, 2018, 1463579. [CrossRef]

40. Elansary, H.O.; Yessoufou, K.; Shokralla, S.; Mahmoud, E.A.; Skaicka-Wozniak, K. Enhancing mint and basil oil composition and antibacterial activity using seaweed extracts. Ind. Crop Prod. 2016, 92, 50-56. [CrossRef]

41. Abd El-Kareem, M.S.M.; Mohamed, A.R.; Elansary, H.O.; Al-Mana, F.A. Mass Spectral Fragmentation of Pelargonium graveolens Essential Oil Using GC-MS Semi-Empirical Calculations and Biological Potential. Processes 2020, 8, 128. [CrossRef]

42. Gedara, S.; Galala, A. New cytotoxic spirostane saponin and biflavonoid glycoside from the leaves of Acacia saligna (Labill.) H.L. Wendl. Nat. Prod. Res. 2013, 28, 324-329. [CrossRef] [PubMed]

43. Dube, J.S.; Reed, J.D.; Ndlovu, L.R. Proanthocyanidins and other phenolics in Acacia leaves of Southern Africa. Anim. Feed Sci. Technol. 2001, 91, 59-67. [CrossRef]

44. Bishai, B.; Badria, F.; Maatooq, G.; Amer, M. Antioxidant and Immunomodulatory Constituents of Henna Leaves. Z. Nat. C J. Biosci. 2004, 59, 468-476. [CrossRef]

45. Mahmoud, Z.F.; Salam, N.A.; Khafagy, S.M. Constituents of henna leaves (Lawsonia inermis L.) growing in Egypt. Fitoterapia 1980, 51, 153-155.

46. Ostovari, A.; Hoseinieh, S.M.; Peikari, M.; Shadizadeh, S.R.; Hashemi, S.J. Corrosion inhibition of mild steel in $1 \mathrm{M} \mathrm{HCl}$ solution by henna extract: A comparative study of the inhibition by henna and its constituents (Lawsone, Gallic acid, $\alpha$-d-Glucose and Tannic acid). Corros. Sci. 2009, 51, 1935-1949. [CrossRef]

47. Ran, J.; Sun, H.; Xu, Y.; Wang, T.; Zhao, R. Comparison of Antioxidant Activities and HPLC Analysis of Polyphenol from Different Apple Varieties. Int. J. Food Prop. 2016, 19. [CrossRef]

48. Zhang, M.; Swarts, S.G.; Yin, L.; Liu, C.; Tian, Y.; Cao, Y.; Swarts, M.; Yang, S.; Zhang, S.B.; Zhang, K.; et al. Antioxidant properties of quercetin. Adv. Exp. Med. Biol. 2011, 701, 283-289. [CrossRef]

49. Murakami, Y.; Kawata, A.; Ito, S.; Katayama, T.; Fujisawa, S. Radical-Scavenging and Anti-inflammatory Activity of Quercetin and Related Compounds and Their Combinations Against RAW264.7 Cells Stimulated with Porphyromonas gingivalis Fimbriae. Relationships between Anti-inflammatory Activity and Quantum Chemical Parameters. In Vivo 2015, 29, 701-710.

50. Velderrain-Rodríguez, G.R.; Torres-Moreno, H.; Villegas-Ochoa, M.A.; Ayala-Zavala, J.F.; Robles-Zepeda, R.E.; Wall-Medrano, A.; González-Aguilar, G.A. Gallic Acid Content and an Antioxidant Mechanism Are Responsible for the Antiproliferative Activity of 'Ataulfo' Mango Peel on LS180 Cells. Molecules 2018, 23, 695. [CrossRef]

51. Kilic, I.; Yesiloglu, Y. Spectroscopic studies on the antioxidant activity of p-coumaric acid. Spectrochim. Acta A Mol. Biomol. Spectrosc. 2013, 115, 719-724. [CrossRef]

52. Buravlev, E.V.; Dvornikova, I.A.; Schevchenko, O.G.; Kutchin, A.V. Synthesis and Antioxidant Ability of Novel Derivatives Based on para-Coumaric Acid Containing Isobornyl Groups. Chem. Biodivers. 2019, 16, e1900362. [CrossRef] [PubMed]

53. Shukla, S.; Gupta, S. Apigenin: A promising molecule for cancer prevention. Pharm. Res. 2010, $27,962-978$. [CrossRef] [PubMed]

54. Ganeshpurkar, A.; Saluja, A.K. The Pharmacological Potential of Rutin. Saudi Pharm. J. 2017, 25, $149-164$. [CrossRef] [PubMed]

55. Hu, Z.; Zhao, P.; Xu, H. Hyperoside exhibits anticancer activity in non-small cell lung cancer cells with T790M mutations by upregulating FoxO1 via CCAT1. Oncol. Rep. 2020, 43, 617-624. [CrossRef]

56. Zhang, Y.; Dong, H.; Zhang, J.; Zhang, L. Inhibitory effect of hyperoside isolated from Zanthoxylum bungeanum leaves on SW620 human colorectal cancer cells via induction of the p53 signaling pathway and apoptosis. Mol. Med. Rep. 2017, 16, 1125-1132. [CrossRef]

57. Ghițu, A.; Schwiebs, A.; Radeke, H.H.; Avram, S.; Zupko, I.; Bor, A.; Pavel, I.Z.; Dehelean, C.A.; Oprean, C.; Bojin, F.; et al. A Comprehensive Assessment of Apigenin as an Antiproliferative, Proapoptotic, Antiangiogenic and Immunomodulatory Phytocompound. Nutrients 2019, 11, 858. [CrossRef]

58. Wang, P.; Heber, D.; Henning, S.M. Quercetin increased the antiproliferative activity of green tea polyphenol (-)-epigallocatechin gallate in prostate cancer cells. Nutr. Cancer 2012, 64, 580-587. [CrossRef] 
59. Zhao, M.H.; Yuan, L.; Meng, L.Y.; Qiu, J.L.; Wang, C.B. Quercetin-loaded mixed micelles exhibit enhanced cytotoxic efficacy in non-small cell lung cancer in vitro. Exp. Ther. Med. 2017, 14, 5503-5508. [CrossRef]

60. Karpiński, T.; Adamczak, A.; Ożarowski, M. Antibacterial activity of apigenin, luteolin, and their C-glucosides. In Proceedings of the 5th International Electronic Conference on Medicinal Chemistry, Poland, 1-30 November 2019. [CrossRef]

61. Bag, A.; Chattopadhyay, R.R. Synergistic antibacterial and antibiofilm efficacy of nisin in combination with p-coumaric acid against food-borne bacteria Bacillus cereus and Salmonella typhimurium. Lett. Appl. Microbiol. 2017, 65, 366-372. [CrossRef]

62. Hirai, I.; Okuno, M.; Katsuma, R.; Arita, N.; Tachibana, M.; Yamamoto, Y. Characterisation of anti-Staphylococcus aureus activity of quercetin. Int. J. Food Sci. Technol. 2010, 45, 1250-1254. [CrossRef]

63. Jaisinghani, R. Antibacterial properties of quercetin. Microbiol. Res. 2017, 8. [CrossRef]

64. Sze Kwan, L.; Tzi Bun, N. Acafusin, a Dimeric Antifungal Protein from Acacia confusa Seeds. Protein Pept. Lett. 2010, 17, 817-822. [CrossRef] [PubMed]

65. Smiljkovic, M.; Stanisavljevic, D.; Stojkovic, D.; Petrovic, I.; Marjanovic Vicentic, J.; Popovic, J.; Golic Grdadolnik, S.; Markovic, D.; Sankovic-Babice, S.; Glamoclija, J.; et al. Apigenin-7-O-glucoside versus apigenin: Insight into the modes of anticandidal and cytotoxic actions. EXCLI J. 2017, 16, 795-807. [CrossRef] [PubMed]

66. Li, S.; Zhang, Z.; Cain, A.; Wang, B.; Long, M.; Taylor, J. Antifungal Activity of Camptothecin, Trifolin, and Hyperoside Isolated from Camptotheca acuminata. J. Agric. Food Chem. 2005, 53, 32-37. [CrossRef] [PubMed]

67. Morales, J.; Mendoza, L.; Cotoras, M. Alteration of oxidative phosphorylation as a possible mechanism of the antifungal action of p-coumaric acid against Botrytis cinerea. J. Appl. Microbiol. 2017, 123, 969-976. [CrossRef]

68. Rocha, M.F.G.; Sales, J.A.; da Rocha, M.G.; Galdino, L.M.; de Aguiar, L.; Pereira-Neto, W.d.A.; de Aguiar Cordeiro, R.; Castelo-Branco, D.d.S.C.M.; Sidrim, J.J.C.; Brilhante, R.S.N. Antifungal effects of the flavonoids kaempferol and quercetin: A possible alternative for the control of fungal biofilms. Biofouling 2019, 35, 320-328. [CrossRef] [PubMed]

69. Yessoufou, K.; Daru, B.H.; Tafirei, R.; Elansary, H.O.; Rampedi, I. Integrating biogeography, threat and evolutionary data to explore extinction crisis in the taxonomic group of cycads. Ecol. Evol. 2017, 7, 2735-2746. [CrossRef]

70. Salem, M.Z.M.; El-Hefny, M.; Nasser, R.A.; Ali, H.M.; El-Shanhorey, N.A.; Elansary, H.O. Medicinal and biological values of Callistemon viminalis extracts: History, current situation and prospects. Asian Pac. J. Trop. Med. 2017, 10, 229-237. [CrossRef]

(C) 2020 by the authors. Licensee MDPI, Basel, Switzerland. This article is an open access article distributed under the terms and conditions of the Creative Commons Attribution (CC BY) license (http://creativecommons.org/licenses/by/4.0/). 